\title{
Mark Blaug (1927-2011)
}

\author{
William J. Baumol
}

(C) Springer Science+Business Media New York 2012

On November 19, 2011, we lost Mark Blaug, one of the scarce polymaths of our discipline. He contributed an amazing number of articles and books in a great variety of arenas and fields within economics, including economic theory, history of economic thought, economic methodology, education, economic growth, art, politics, philosophy, and science. In each arena that he entered, he contributed illuminating and novel ideas, pointed out new directions, and stimulated the reader-like Poirot- "furiously to think."

\section{On the history of economic ideas}

Ironically, as Mark himself recognized, perhaps his most remembered work is his Economic Theory in Retrospect (1962), a book translated into an impressive array of languages. ${ }^{1}$ In later years, Mark came to regard this as one of his less significant contributions-much as Hicks eventually viewed his Value and Capital. Here I am driven to disagree with Mark, as I did with Hicks. Both shifted their interests over the years and subsequently made significant contributions in new arenas. But this in no way reduces the significance of their earlier work.

As a field of study, the history of economic ideas occupies a curious position. It has attracted great scholars, including Schumpeter, Viner, and Robbins, among many others. During the time of Alfred Marshall, for instance, no scholar could be considered respectable without demonstrating a reasonable understanding of earlier

\footnotetext{
${ }^{1}$ Blaug (1962).

W. J. Baumol ( $₫)$

New York University, New York, NY, USA

e-mail: william.baumol@stern.nyu.edu

W. J. Baumol

Princeton University, Princeton, NJ, USA
} 
writings. Yet in today's journals, the topic is nearly forgotten, and few students seek out courses in the subject. ${ }^{2}$ Mark had the misfortune to be caught up in this transition. Having taught the subject at Yale early in his career, he was denied tenure on the grounds that the subject area no longer merited the devotion of resources. $^{3}$

I do not know the content of Mark's courses on this subject, but I do know his great book, which offers much more than simply another explanation of what earlier thinkers in economics meant to say, how they have been misunderstood, and how forces, such as religion, have influenced the content of their work. Rather, Mark's book examines the past in order to determine what it implies for research in the future. His book is unique in that it seeks to determine where we go from here, using analytic tools more sophisticated than those available to the predecessors he examined. In short, Mark helped to show us how we can build a richer body of economic analysis on the foundations of the work of our predecessors.

Here, it is important to emphasize that the mathematics employed in Mark's book is not inserted as mere decoration but, rather, as an instrument to carry earlier ideas forward. Surely, this helps to explain the book's continuing popularity throughout the world and the unending stream of translations it has elicited.

\section{Combating poverty in practice and theory}

The struggle with poverty entered Mark's ideas in several ways. One was his direct experience, which entailed work to improve education in third-world countries in Africa and Southeast Asia, as part of consulting missions for several United Nations agencies. But he rapidly became disillusioned and concluded that the governments in many developing countries were exploiting the visits of foreign economists simply to obtain the funding from the international agencies, which they often used for their private benefit. However, Mark did not give up his concern about issues relating to poverty. His groundbreaking work on the Poor Laws, for instance, followed a path that was entirely original and entailed painstaking slogging through parish records. ${ }^{4}$

Moreover, during his early period, Mark was a confirmed Marxist and even a card-carrying member of the Communist party in the United States. Here, too, he became disillusioned (with the aid of work by Hayek, Popper, Stigler, and others) and swung back toward the center. ${ }^{5}$ Eventually, Mark came to believe (like the

\footnotetext{
2 Jacob Viner once noted that in any academic discipline the amount of attention paid to the history of the subject is inversely related to the rapidity with which new ideas and new methods appear in the field. Thus, disciplines in which new ideas are constantly appearing can be expected to attract little attention to the work of earlier contributors. Although Viner himself had devoted much time and energy to the history of economic ideas and had made major contributions to the field, he saw the absence of concern with the work of predecessors as a token of progress in our field.

3 Indeed, at Princeton my course in the history of economic ideas-at first overcrowded, even attracting faculty members from other departments - suddenly saw enrollment fall to six students.

4 Blaug (1963, 1964).

5 Here, it is important to mention Imre Lakatos, the Hungarian philosopher of mathematics and science, who aroused Mark's interest in Popper's work and eventually became Mark's good friend. Lakatos had
} 
present author) that capitalism is historically the most successful engine of economic growth and, hence, the most promising instrument for the elimination of poverty-though it requires various forms of intervention to restrain inequality, reduce poverty, ensure the availability of health care and education, and provide support for culture and the arts. Underlying this view, was Mark's belief in the urgent need to stimulate the economic growth that alone promises to provide the resources required to eliminate the economic misery that besets the world's poor.

This position, in turn, drove Mark to rethink his views on economic analysis, focusing on Schumpeter's work as the foundation of a valid and useful analysis of the mechanism of economic growth. In keeping with this approach, Mark dismissed the theorists who wrote about growth as though it were attributable primarily to the expansion of input quantities - that is, the size of the labor force and magnitude of investment. Arguably, it was the ease of theoretical formulation that led other investigators to focus their work on quantifiable variables, rather than on the forces that drive innovation and its adoption, in practice. But evidently, it is innovation that spurred the unprecedented growth in recent centuries. I must emphasize my full agreement with Mark's conclusion and its implications for the directions that should be taken by economic analysis - even if it precludes simple and apparently rigorous mathematization.

\section{On the economics of the arts}

Mark's wife, Ruth Towse, is perhaps better known for her work on the economics of the arts-an area in which she is indisputably a leader. However, Mark also made several significant contributions to that field. He edited one of the first collections on the subject, The Economics of the Arts (1976), which included several of his own papers. ${ }^{6}$ Another of his noted articles "Why Are Covent Garden Seat Prices So High?" was published in this journal soon after. ${ }^{7}$ More recently, Mark provided valuable contributions to a book edited by Ruth, A Handbook of Cultural Economics (2010). ${ }^{8}$ In addition to his avid interest in the arts as consumer, Mark was evidently a master of these economic issues.

\section{Mark Blaug in person}

There is much more to Mark than a set of publications. The times I spent with him and his wife Ruth were always a great pleasure and a source of intellectual and creative stimulation. Unfortunately, we three were almost always in agreement-

\footnotetext{
Footnote 5 continued been a communist under Hungary's Nazi collaborationist government and later became an anti-communist under the Soviet government.

6 Blaug (1976).

7 Blaug (1978).

8 Blaug (2010).
} 
though I learned even more and took even greater pleasure from the few occasions where our views differed.

Mark was indeed a citizen of the world, having lived and taught—not merely visited-in Amsterdam, London, New York, and Paris. These cities, along with his experiences in the developing world, kept him well armed with new ideas and fresh sources of stimulation. In the United States, for instance, he was stimulated to think about the history of economic ideas and methodology; in London, he was led to examine the economics of education; and in Paris, he found books, notably Popper's writings, that opened still other new vistas for him. In each place, he gave as good as he got, responding to whatever he learned with new ideas of his own.

I cannot resist closing with Mark's own words - a story about his childhoodtaken from an autobiographical essay he published in The American Economist. ${ }^{9}$

"I have personal reasons for appreciating the importance of product innovations. My father manufactured raincoats in Holland in the 1930s. A Swede transformed the business in 1932 by inventing the poplin raincoat; before that raincoats were always made of artificial rubber. My father found himself with thousands of unsalable rubber raincoats in 1933, the depth of the Great Depression in the Netherlands, and faced bankruptcy...so he offered his entire stock at a penny a piece to $C \& A$, the leading clothing store in Amsterdam. They were so impressed by his boldness that they gave him an order for poplin raincoats if he could learn to manufacture them. He went to Sweden, poached a tailor and a cutter, and filled the order. That led to more orders and still more orders and by 1935, he was the Raincoat King of the Netherlands and a self-made millionaire. His good fortune did not last very long because in 1940, the Germans invaded Holland and we lost it all. When this rags-to-riches story started, I was six years old; when it ended, I was twelve. In short, I have good reasons to think that new products can make a difference."

\section{References}

Blaug, M. (1962). Economic theory in retrospect. Homewood, Illinois: Richard D. Irwin.

Blaug, M. (1963). The myth of the old poor law and the making of the new. Journal of Economic History, 23(2), 151-184.

Blaug, M. (1964). The poor law report reexamined. Journal of Economic History, 24, 229-245.

Blaug, M. (Ed.). (1976). The economics of the arts. Boulder, Colorado: Westview Press.

Blaug, M. (1978). Why are covent garden seat prices so high? Journal of Cultural Economics, 2(1), 1-20.

Blaug, M. (1994). Not only an economist-Autobiographical reflections of a historian of economic thought. The American Economist, 38(2), 12-27.

Blaug, M. (2011). Cultural entrepreneurship (with Ruth Towse) and Welfare economics. In R. Towse (Ed.), A handbook of cultural economics, 2nd edn. Cheltenham, UK and Northampton, MA: Edward Elgar, 153-157; 425-430, respectively.

\footnotetext{
9 Blaug (1994).
} 